Cahiers $d u$ MONDE RUSSE

\section{Cahiers du monde russe}

Russie - Empire russe - Union soviétique et États indépendants

\section{$54 / 3-4 \mid 2013$}

L'expérience soviétique à son apogée - Culture et société des années Brežnev / Volume II

\title{
Back-Office МИХАИЛА СУСЛОВА ИЛИ КЕМ И КАК ПРОИЗВОДИЛАСЬ ИДЕОЛОГИЯ БРЕЖНЕВСКОГО ВРЕМЕНИ
}

Le «back-office» de Suslov ou comment et par qui était produite l'idéologie du temps de Brežnev

Mikhail Suslov's back office: The who and how of ideological production during the Brezhnev era

\section{Nikolaj Mitrohin}

\section{(2) OpenEdition} Journals

Édition électronique

URL : https://journals.openedition.org/monderusse/7955

DOI : 10.4000/monderusse. 7955

ISSN : $1777-5388$

Éditeur

Éditions de l'EHESS

Édition imprimée

Date de publication : 1 juillet 2013

Pagination : 409-440

ISBN : 9782713224393

ISSN : $1252-6576$

Référence électronique

Nikolaj Mitrohin, «Back-Office Михаила Суслова Или Кем И Как Производилась Идеология Брежневского Времени», Cahiers du monde russe [Онлайн], 54/3-4 | 2013, Выложить онлайн 01 juillet 2016, Наводить справки в 02 septembre 2022. URL: http://journals.openedition.org/ monderusse/7955; DOI: https://doi.org/10.4000/monderusse.7955 


\section{ВАСК-ОFFІСЕ МИХАИЛА СУСЛОВА ИЛИ КЕМ И КАК ПРОИЗВОДИЛАСЬ ИДЕОЛОГИЯ БРЕЖНЕВСКОГО ВРЕМЕНИ}

Интервью с бывшим работником аппарата ЦК КПСС Алексеем Козловским всегда проходили по одному сценарию. Я приходил в его квартиру в отличном по советским меркам доме из светлого кирпича в районе московской станции метро Кунцевская - где в 1960-1970-е годы управлением делами ЦК КПСС были построены два жилых комплекса. Он открывал мне дверь квартиры на тринадцатом этаже. Я снимал пальто в прихожей и проходил в его узкий рабочий кабинет, из окна которого открывался прекрасный вид на соседние дома и часть парка. Кабинет был сверху донизу заставлен книжными полками с советскими изданиями писателей-классиков и литературоведческими работами, преимущественно 1960-1980-х годов. Я садился на старый стул, хозяин дома - за красивый потертый рабочий стол, покрытый зеленым сукном.

Два с половиной или три часа он неторопливо отвечал на мои вопросы. Никаких предложений выпить чаю, никаких посторонних разговоров. Дисциплинированные родные ни разу не побеспокоили нас своим вторжением, что было редкостью по сравнению с обычным течением встреч в домах его коллег. Потом я вставал, прощался и уходил. Хозяин любезно провожал меня до двери, приглашал заходить ещё.

Четкость, дисциплинированность, этикет и отсутствие пустопорожних разговоров - качества, как можно было понять из наших интервью, перенятые моим собеседником у своего отца. Тот был потомственным тамбовским дворянином по происхождению, офицером императорской армии, который в СССР потерял надежду на продолжение военной карьеры (о чём всю жизнь жалел), но зато благодаря своим административным талантам смог возглавить в послевоенные годы одно из управлений Министерства лесного хозяйства РСФСР. Аристократическая семья, в которой вырос мой собеседник, сумела выжить в советских условиях, вполне вероятно, благодаря этим

Благодарю Софью Тимофееву за редакторскую правку. 
качествам, а также, безусловно, везению. Внучатый племянник (по матери) сразу двух членов Государственного совета Российской империи - Николая и Константина Ясюнинских ${ }^{1}$, потомственный дворянин Алексей Козловский самый знатный по социальному происхождению человек из тех примерно ста двадцати бывших работников аппарата ЦК КПСС, которых мне удалось опросить за последние семь лет ${ }^{2}$.

Алексей Козловский был аристократом не только по факту рождения, но и по той культурной среде, в которой он воспитывался в детстве. На него оказали влияние и круг гимназических друзей матери - заметных советских ученых; и артистическая среда, с которой его знакомила тётя, Ксения Ивановна Ясюнинская - актриса Малого театра; и близкие родственники отца - ведущие советские специалисты по заповедным территориям - все как один из «бывших». Ещё подростком он вбирал в себя «несоветские» знания. «Доктор Живаго» был им прочитан в рукописи ещё в 1948 году, но не произвёл впечатления. Козловский учился в лучшем советском образовательном учреждении - Московском государственном университете. И, наконец, Козловский стал редактором крупного советского издательства, в котором занимался преимущественно редактурой и изданием русских поэтов первой трети XX века. В первую очередь Маяковского и Есенина. И потому бывал в домах Лили Брик и Виктора Шкловского.

Таким образом, Козловский с его происхождением и кругом общения является хорошим примером передачи культурного наследия Серебряного века в советском социуме. Как же тогда объяснить то, что человек с таким культурным багажом и кругом знакомств почти двадцать лет (в 1971-1989 годах) проработал в Отделе пропаганды ЦК КПСС и, в частности, занимал там не последнюю должность - заведующего сектором журналов? Что он был одним из основных авторов докладов для Михаила Суслова? Что был отнюдь не «либералом», а наоборот, придерживался консервативных «антидиссидентских» взглядов?

С другой стороны, а что мы вообще знаем о творцах советской идеологии и пропаганды в брежневское время? Помимо общеизвестной фигуры Михаила Суслова, который, впрочем, также малоизучен (в частности, не существует его современной научной биографии $\left.{ }^{3}\right)$, кто были те люди, которые производили советский пропагандистский продукт, и где они работали? Как была устроена и как координировалась система советской пропаганды в этот период? Чем руководствовались в своей работе люди, которые в ней участвовали? Имели ли они собственную позицию и могли ли её отстаивать?

При всём многообразии институций, которые участвовали в выработке советской идеологии и разработке тех культурных символов, которые она

1. http://liga-ivanovo.narod.ru/istalm04-06.htm; http://zarubezhje.narod.ru/gi/E_190.htm

2. Фото и официальная биография по ссылке - http://www.imli.ru/structure/new/kozlov. php. Интервью с А. Козловским. Москва. 05.10.04; 18.09.2007; 23.04.08, 16.09.2008; 08.04.2009. Аудиозапись и расшифровка интервью. Электронный архив автора.

3. Единственная известная мне биография Суслова была опубликована 15 лет назад: Serge Petroff, The Red Eminence: A Biography of Mikhail A. Suslov, Cliffton, NJ: Kingston Press, 1988 
производила, координирующие функции были возложены на одну из них Отдел пропаганды аппарата ЦК КПСС ${ }^{4}$. Фактически в сфере идеологии он выполнял функции back-office официального центра принятия политических решений в этой сфере - Политбюро. Выражение back-office используется в современной деловой терминологии для обозначения реального офиса некой организации, отличающегося от front-office, предназначенного для общения с клиентами и прессой. В некоторых ситуациях back-office имет дурную славу, потому как там занимаются «темными делишками», выгодными только руководству компании и тщательно скрываемыми как от клиентов и общественности, так и от акционеров и многих рядовых сотрудников, работающих в компании.

Аппарат ЦК КПСС в целом был подобным back-office в рамках советской политической машины. При наличии официальных front-office, носящих характер публичного представительства системы перед населением страны и иностранцами (например, Верховный Совет, ВЛКСМ, Союз писателей, Советский Комитет защиты мира, газеты), а также, разумеется, формального партийного парламента - Центрального комитета и как бы избираемого им Политбюро-аппарат ЦК КПСС во многом выполнял роль реального организационного центра, готовящего документацию для Политбюро и Секретариата ЦК. Они вместе определяли, кто будет избран в новый состав ЦК КПСС, номинально контролирующего исполнение решений, принятых этими структурами. Аппарат ЦК КПСС по своей инициативе самостоятельно готовил решения, позже принимаемые к рассмотрению Политбюро. Он вел финансовые и хозяйственные дела Политбюро и ЦК КПСС. При этом его деятельность была окутана тайной, а его малоизвестные широкой публике функционеры весили в политической и административно-хозяйственной жизни страны нередко поболее, чем члены ЦК КПСС.

Часть членов Политбюро одновременно были секретарями ЦК КПСС (например, Леонид Брежнев, Андрей Кириленко, Михаил Суслов), то есть реально приводили в движение рычаги управления партией. Они лично курировали различные отделы аппарата ЦК КПСС, которые служили их коллективными помощниками в разработке и проведении тех или иных инициатив.

В рамках статьи будет охвачена деятельность Отдела пропаганды ЦК КПСС с 1966 по 1985 год. Это был период его стабильного существования как административной единицы. Он наступил после почти двух десятилетий административных реформ, начавшихся с преобразования Управления пропаганды и агитации аппарата ЦК ВКП (б) в 1948 году и приведших к разделению отдела на два - общесоюзный и «по РСФСР» в 1955-1965 годах, потом сведению его вместе с двумя другими отделами, занимавшимися схожими вопросами (науки и культуры), «под крышу» Идеологической комиссии ЦК КПСС. Финальной

4. Текст доклада является переработанной версией working papers, представленных в разных вариантах на конференции «Проекты модерности: конструктируя «советское» в европейской перспективе.» (Пермский государственный университет, 24-26.06.2013) и на коллоквиуме в Princeton university (18.11.2013). Благодарю Александра Резника и Сергея Ушакина за предоставленную возможность обсудить эти тексты. 
датой исследования я ставлю 1985 год - поскольку с приходом Михаила Горбачёва наступает новая эпоха и классическая модель деятельности аппарата ЦК КПСС, его взаимосвязей с другими ведомствами начинает разрушаться.

\section{Предшественники и источниики}

Аппарат ЦК КПСС этого периода как самостоятельное учреждение пока не становился объектом исследования со стороны специалистов. Политологи, а затем историки сосредотачивали свои усилия на анализе деятельности Политбюро ЦК КПСС 5 , персональном составе членов ЦК КПСС ${ }^{6}$, но практически не интересовались аппаратом как таковым. Пока, за исключением ряда сборников документов, посвященных влиянию аппарата ЦК КПСС в сфере культуры$^{7}$, мне известно только одно научное исследование, касающееся одной из многочисленных функций аппарата - внешнеполитической пропаганды ${ }^{8}$.

Основными источниками для данной статьи послужили материалы моего проекта по изучению аппарата ЦК КПСС периода 1953-1985 годов, который проводится с декабря 2006 года на средства немецких фондов Gerda Henkel (2006-2008) и Deutsche Forschungsgemeinschaft (2009-2012) и при поддержке Forschungsstelle an den Bremen universität, в которой я работаю с декабря 2008 года9. В рамках проекта были проведены «глубокие интервью» с более чем 120 бывшими сотрудниками аппарата ЦК КПСС (не считая около 40 интервью с другими лицами, тесно сотрудничавшими с ними в исследуемый период) и собрана подробная персональная биографическая информация ещё на более чем 100 человек.

В данной статье используется биографический массив, состоящий из 36 подробных биографий сотрудников отдела периода со 2-й половины

5. См., например: А. Сушков, Президиум ЦК КПСС в 1957-1964 г2.: Личности и власть, Свердловск: УрО РАН, 2009.

6. Ronald J. Hill, Peter Frank, The Soviet Communist Party, Second edition, London: George Allen and Unwin, 1983; Roy D. Laid, The Politburo: Demographic Trends, Gorbachev and the Future, Boulder, CO: Westview Press (Special Studies on the Soviet Union and Eastern Europe), 1986; Evan Mawdsley, Stephen White, The Soviet elite from Lenin to Gorbachev: The Central Committee and its Members, 1917-1991, Oxford university press, 2000, (изданная также в русском переводе: Модсли Э., Уайт С. Советская элита от Ленина до Горбачева: Центральный комитет и его члены. 1917-1991 г2., М.: РОССПЭН, 2011); William Tompson, The Soviet Union under Brezhnev, Harlow: Pearson Longman, 2003; O. Крыштановская, Анатомия российской элиты, М.: Захаров, 2005.

7. Культура и власть от Сталина до Горбачева. Аппарат ЦК КПСС и культура. 1958-1964, Документы, М.: РОССПЭН, 2005 и последующие издания этой серии.

8. См.: Л. Силина, Внешнеполитическая пропаганда в СССР в 1945-1985 г2. (по материалам отдела пропаганды и агитации ЦК ВКП(б)-КПСС), М.: РОССПЭН, 2011. Правда, её автор не смогла реализовать поставленную перед собой задачу.

9. Здесь уместно поблагодарить профессора Dietrich Beyrau, который всё это время был неформальным куратором проекта и оказывал ему всё возможное содействие, а также профессоров Jörg Baberowski и Susanne Schattenberg, которые заботились о развитии проекта и на разных этапах поддерживали его и с научной и с административной точки зрения. 
1950-х по 1985 год. 25 из них основаны на интервью с бывшими сотрудниками Отдела ${ }^{10}$, одиннадцать на других типах источников - мемуарах, «памятных книгах», интервью с родственниками. Кроме того в моём распоряжении находятся официальные биографии (т.н. объективки) и краткие биографии ещё примерно 50 сотрудников отдела этого периода подтверждающие своими основными параметрами тот факт, что выбранные мною биографии не являются «уникальными».

Интервью расшифрованы и находятся в электронном виде в моём архиве ${ }^{11}$. В большинстве случаев проводилось несколько встреч по методике «глубоких интервью». Опрос проводился по общему списку тем для разговора (около 300). Они включали подробное выяснение биографии информанта, его политических и культурных предпочтений, описание его профессиональной деятельности в аппарате ЦК КПСС и сопровождавших эту деятельность привилегий. Целью опроса (как и проекта в целом) было создание обширной базы свидетельств сотрудников аппарата о самих себе, общественных, политических и культурных реалиях, которые наблюдались ими в процессе их жизни и, разумеется, работы в ЦК КПСС. Первые беседы служили основой для составления дополнительного списка вопросов, позволяющих уточнить индивидуальный опыт информанта.

Для проекта и данной статьи привлекались и другие источники мемуарного характера: интервью, данные сотрудниками отдела журналистам и исследователям; мемуары ${ }^{12}$, в том числе и не опубликованные ${ }^{13}$, «памятные книги» ${ }^{14}$. От одного из бывших сотрудников отдела, Юрия Лобова, удалось

10. В. Алексеев, С. Арутюнян, Л. Вознесенский, А. Гаврилов, А. Козловский, Р. Косолапов, В. Костров, В. Кувенева, А. Лисин, Ю. Лобов, П. Лучинский, В. Медведев, В. Михайлов, П. Московский, М. Ненашев, А. Поляков, А. Сазонов, Ю. Сапожников, В. Сапрыкин, Ю. Скляров, В. Суходеев, В. Фединин, Н. Фролов, Н. Черных, А. Яковлев.

11. Выражаю глубокую благодарность Ольге Сибиревой, взявшей на себя труд по расшифровке всех интервью, сделанных в ходе проекта и самой сделавшей значительную их часть.

12. С. Арутюнян, О прошлом и настоящем, М., 2009; Н. Биккенин, Как это было на самом деле: Сиень общественной и частной жизни, М.: Academia, 2003; Л. Вознесенский, Истины ради..., М.: Республика, 2004; В. Еременко, Отче... ХХ век: Семейный роман, М.: Литературная Россия, 2004; В.Г. Захаров, От Смольного до правительства СССР: Записки министра культуры, М.: Издательство РАГС, 2010; В. Кувенева, Взгляд сквозь призму времени, М., 2011; И. Лаптев, Власть без славы, М.: Олма-пресс, 2002; В. Медведев, Прозрение, миф или предательство? К вопросу об идеологии перестройки, М.: Евразия, 1998; М. Ненашев, Заложник времени, М.: Прогресс, 1993; А.Н. Сахаров, «Трудный путь в науке» в Россия: Народ. Правители. Цивилизация, М.: ИРИ РАН, 2004. С. 903-927; Г.Л. Смирнов, Уроки минувщего, М.: РОССПЭН, 1997; Б. Стукалин, Годы, дороги, лица ... М.: Фонд имени И.Д. Сытина, 2002; В.И. Суханов, Советское поколение и Геннадий Зюганов: Время решительных, М.: ИТРК РСПП, 1999; А.А. Яковлев, сост., Александр Яковлев. Избранные интервью: 1992-2005, М.: МФД, 2009; А.Н. Яковлев Горькая чаша, Ярославль: Верхне-Волжское книжное издательство, 1994.

13. Например, А. Лисин, Метаморфозы духа, 2012. Рукопись книги. Электронная версия.

14. Распространенный в современной России жанр сборников, подготовленных и опубликованных родственниками и друзьями в память недавно скончавшегося поли- 
получить уникальный источник: рабочие записные книжки, подробно зафиксировавшие повседневную деятельность сектора печати, в котором работал автор, в 1981-1984 годах, а также отражающие содержание различных «общеотдельских» совещаний этого периода. Фрагменты записей из личных записных книжек за 1978-1982 годы, полученные от бывшего главного редактора журнала «Человек и закон» Сергея Семанова, позволяют расширить представления об одном из видов мероприятий отдела - «брифингов», о которых подробнее я буду говорить ниже ${ }^{15}$.

Ценным источником стали полученные от бывших сотрудников ЦК КПСС телефонные справочники аппарата ЦК КПСС и собственные справочники Отдела пропаганды за 1976-1985 годы, которые в систематизированном виде не только позволили точно установить структуру отдела и персональный состав его сотрудников, но и проследить динамику их изменений.

Определенную пользу для данной статьи принесла и работа с документами фонда Отдела пропаганды ЦК КПСС по РСФСР периода 1956-1966 годов, который находится в РГАСПИ (Ф. 556, Оп. 15).

\section{Роль Отдела пропаганды в аппарате ЦК КПСС}

Отдел пропаганды был одним из более чем 20 отделов аппарата ЦК КПСС рассматриваемого периода. Он входил в неофициальный блок идеологических отделов, который кроме него составляли отдел культуры и отдел науки, вузов и средней школы. Этот блок напрямую подчинялся «рабочему» секретарю ЦК КПСС по идеологии - в 1965-1974 годах это был Петр Демичев, в 1976-1987 - Михаил Зимянин. Рабочий секретарь, в свою очередь, подчинялся упоминавшемуся выше члену Политбюро, курировавшему идеологию - таковым большую часть исследуемого периода был Михаил Суслов, затем его сменил Юрий Андропов, а затем и Константин Черненко.

Отдел пропаганды, насчитывающий в своих рядах порядка 120 ответственных и технических сотрудников, считался в аппарате «вторым» отделом по значимости - после отдела Организационно-партийной работы (далее - Орготдел). Наряду с Орготделом и Отделом административных органов он был в числе трех наиболее крупных и влиятельных

тического, обшественного, экономического деятеля содержащих компиляцию текстов (мемуаров, интервью, дневниковых записей, переписки, собственных литературных и публицистических произведений покойного) и документов (архивных и фото). В числе использованных для этой статьи см.: Академик Иван Тимофеевич Фролов: Очерки. Воспоминания. Избранные статьи. М.: Наука, 2001; Виктор Поляничко. Жизнь и судьба: Документальные повести, размышления, воспоминания, документы, Рук. проекта М.Ф. Ненашев, Редактор-составитель В.А. Лысенко, Оренбург: Оренбургское книжное издательство, 2007; Иван Тимофеевич Фролов, М.: Наука, 2006; По делам и честь: О Борисе Ивановиче Стукалине, М.: Фонд имени И.Д. Сытина, 2005; Н. Лапин и другие, сост., Человек ХХ столетия: Воспоминания о Биккенине Н.Б., М.: ГЭОТАР-Медиа, 2011.

15. Записные книжки Ю. Лобова и С. Семанова в настоящее время готовятся к печати. 
Отдел пропаганды, как и другие отделы ЦК, имел свой четко очерченный круг обязанностей. Его отличие от других идеологических отделов заключалось главным образом в ориентации на вопросы создания чисто идеологических продуктов (например, массовой агитационной продукции). Создание продукции, носящей культурный или научный характер, было соответственно делом отделов культуры и науки. А вот распространение созданных их объединенными усилиями продуктов в СМИ было снова делом отдела пропаганды.

\section{Внутренняя структура отдела и основные категории сотрудников}

Структура отдела в течение всего описываемого периода была достаточно стабильна и в целом копировала структуру большинства других крупных отделов ЦК КПСС.

Во главе отдела находился заведующий. Это был партийный бюрократ высокого ранга, имевший возможность прямого общения не только с курировавшим его секретарем ЦК или членом Политбюро, но и с их коллегами. Его ближайший аппарат составляли несколько заместителей заведущего, один из которых официально считался «первым» и замещал заведующего в случае его отлучки. Каждый заместитель курировал несколько секторов, связанных, как правило, близкой тематикой. «Белую кость» отдела представляла собой «группа консультантов» во главе с заведующим. Официально на её сотрудников был возложен анализ ситуации в конкретных сферах, в которых консультанты были специалистами. Свой анализ и предложения они должны были подавать вышестоящему руководству в виде обобщающих «записок». Так именовался особый жанр аналитических документов. Именно поэтому на должности консультантов попадали (не всегда, но преимущественно) ученые с кандидатскими и нередко докторскими степенями и опытные журналисты.

Однако на практике большая часть деятельности консультантов сводилась к писанию различных докладов (или частей докладов) для «первых лиц» членов и кандидатов в члены Политбюро, секретарей ЦК и заведующих отделами. Написание длинных, многочасовых докладов для руководства вообще было одной из главных обязанностей аппарата ЦК. Михаил Суслов был одним из наиболее крупных (но не единственным) «заказчиком» подобных материалов. Тем не менее, поскольку идеологическая проблематика, которую он курировал, составляла значительный объём не только его рядовых публичных выступлений, но также текстов, которые он оглашал на партийных пленумах и съездах, над подготовкой его «речей» едва ли не постоянно трудилась целая группа сотрудников отдела. Они находились в подчинении помощников Суслова, прежде всего Бориса Владимирова.

Основу отдела всё же, как и в других отделах, составляли тематические сектора. Каждый из них обычно состоял из четырех-пяти сотрудников в 
должности инспектора во главе с заведующим сектором. Должность завсектором была низшей командной должностью в аппарате. Основной задачей заведующего сектором было распределение между инструкторами указаний и информации, поступившей от заместителя заведующего или от заведующего отделом, контроль за исполнением указаний, первичная редактура документов, подготовленных инструкторами и предназначенных для передачи «наверх», а также глубокое знакомство с состоянием дел в курируемой им сфере.

Инструктора - самая массовая категория ответственных сотрудников аппарата - отвечали за кураторство конкретных тем, учреждений и территорий. Обычно они курировали одну значимую сферу развития отрасли, несколько организаций или департаментов крупного общесоюзного ведомства, плюс получали под свой контроль решение вопросов тематики своего сектора на нескольких частях территории страны.

Например, сотрудник сектора издательств курировал направление снабжения полиграфической промышленности страны оборудованием, одно крупное или несколько второстепенных издательств в Москве, а также состояние издательского дела в Сибири и, например, в Молдавии.

Особой частью Отдела пропаганды являлась Лекторская группа ЦК КПСС во главе с заведующим, который также подчинялся напрямую главе отдела. Лекторы ЦК КПСС, обладавшие в первую очередь блестящими ораторскими способностями, большим преподавательским или журналистским опытом, а также малодоступной не только обычным гражданам, но и региональному активу информацией, были предназначены для эффективной и полуофициальной передачи нужных Политбюро политических новостей в «массы». Прежде всего в «массы» регионального «партийно-хозяйственного» актива, а также работников крупных промышленных предприятий - которые со времен основания РСДРП считались основной социальной группой поддерживающей партию.

Лекторы ЦК большую часть своего рабочего времени (до 300 дней в году) проводили в бесконечных командировках, поскольку были «нарасхват» у местных партийных организаций, а число их было невелико - не более 18 человек ${ }^{16}$. Ещё одной важной функцией лекторов была «обратная связь» с «массами» - по возвращению в ЦК они отчитывались, в том числе в виде аналитических записок, о том, какие вопросы им задавались в ходе их лекций, какие вопросы были наиболее популярны.

16. Подробно об этом - в интервью Н. Митрохина с лектором, затем заместителем заведующего лекторской группой В. Сапрыкиным, Москва, 10/13.09.2007; 29.05.2008. Аудиозапись и расшифровка интервью. Электронный архив автора. 


\section{Функции секторов отдела}

Чем же занимался отдел? Об этом лучше всего, на мой взгляд, может рассказать краткое описание функций его секторов.

Самыми важными секторами отдела считались два, курировавших идеологическую работу в Российской Федерации и в остальных республиках СССР соответственно. Они так и назывались - «по РСФСР» (им с 1968 по 1985 год руководил Николай Черных) и «по союзным республикам». В первую очередь они контролировали секретарей по идеологии региональных партийных органов и подчиняющихся им заведующих отделами пропаганды. В числе важнейших задач секторов были подбор (и утверждение - если речь шла об инициативе снизу) кадров для занятия этих должностей, а также доведение до секретарей обкомов, крайкомов, рескомов и бюро ЦК союзных республик информации о вопросах, посвященных идеологической сфере, которые обсуждались на заседаниях Политбюро и Секретариата ЦК.

Вторым по значимости в отделе был блок секторов, курировавших медиасферу и издательства. Названия секторов: печати; журналов; телевидения и радио; издательств; полиграфии и книжной торговли - говорят сами за себя. При этом функции у них существенно различались. Сектор печати, курировавший газеты, и сектор журналов были непосредственно вовлечены в редакционно-издательский процесс ${ }^{17}$. Довольно большое количество статей, намеченных к печати, особенно «передовиц» или материалов на острые или политически важные темы, согласовывались редакциями с сотрудниками этих секторов. Они же контролировали прочие материалы, опубликованные в печати. Вместе с тем они относительно мало вмешивались в деятельность партийных СМИ - т. е. журналов «Коммунист», «Агитатор», «Партийное самообразование», газет «Правда», «Советская Россия», «Социалистическая индустрия», поскольку их главные редактора несли персональную ответственность перед секретариатом ЦК КПСС.

По той же причине сектор телевидения и радио имел относительно малое влияние на вещательную политику Гостелерадио СССР. Его глава с 1970 года, Сергей Лапин был в числе личных друзей Леонида Брежнева и исполнял только его указания.

В блоке секторов, контролирующих медиа и издательства, работали в основном профессионалы. Например, журналисты региональных изданий, добравшиеся в своей области до «потолка» карьерного роста - места заместителя главного редактора областной газеты, затем отучившиеся в АОН и

17. Некоторые документы, иллюстрирующие работу сектора в изучаемый период, опубликованы. См.: Пресса в обществе. 1959-2000. Оиенки журналистов и соииологов. Документы, М.: Издательство московской школы политических исследований, 2000 , с. 475-594. На эту же тему существует достаточно поверхностная, не отражающая деятельности отдела и посвященная в основном эпохе перестройки работа: Wolfe Thomas, Govering Soviet Journalism: The press and the socialist person after Stalin, Indiana University Press, 2005. 
принятые прямо из её стен в ЦК. После окончания работы в ЦК они если не уходили на пенсию, то занимали посты главных редакторов московских СМИ и издательств.

Сектор «Физической культуры и спорта», как следует из его названия, курировал Госкомспорт СССР, а также обращал большое внимание на освещение показа спорта по телевидению ${ }^{18}$. В нём работали такие же комсомольские функционеры - выходцы из ЦК ВЛКСМ, что и в Госкомспорте, так что они хорошо находили общий язык. Впрочем, многие из них окончили спортивные вузы или до прихода в ЦК КПСС руководили спортивными организациями, так что они не были новичками в курируемой ими тематике.

Третий блок секторов занимался разными формами прямой пропагандистской работы.

Сектор «массово-политической работы» официально был нацелен на поддержание сети агитаторов и пропагандистов. Эти низовые партийные активисты должны были заниматься пропагандой политики партии внутри трудовых и учебных коллективов, а также агитировать за её поддержку. Для этого, в частности, они должны были проводить «политинформации» - то есть кратко пересказывать коллегам и соученикам политические новости, почерпнутые из газет и журналов, которые те читать не желали.

Гораздо более интересными вещами занимался один из сотрудников сектора - Эмиль Лисавцев. Он координировал работу по контролю за религиозностью и пропаганду «научного атеизма». В этой связи он курировал деятельность Совета по делам религий при Совмине СССР, тесно кооперировался с 5-м управлением КГБ, а также был фактическим начальником над Институтом научного атеизма, входившим в состав Академии общественных наук при ЦК КПСС. В начале 1980 года внутри того же сектора была создана целая группа, занимавшаяся контролем за религиозностью. Сам Лисавцев стал консультантом сектора, а в его фактическое подчинение перешли двое инструкторов-новобранцев. Они были выпускниками ИНА с опытом работы в региональном партийном аппарате ${ }^{19}$.

И, наконец, квинтэссенцией пропагандистских секторов был сектор «партийной пропаганды» (ликвидированный после 1983 года), под началом единственной за 30 лет женщины, находившейся на руководящей работе в отделе - Валентины Байковой. Он занимался уже пропагандой среди членов партии. Для этого он курировал систему домов политпросвещения, а также, по-видимому, кабинеты партучебы и прочие «парткабинеты», существовавшие при райкомах и представлявшие собой на практике небольшие библиотеки.

18. В целом данной теме посвящено довольно обстоятельное исследование (см.: М.Ю. Прозуменщиков, Большой спорт и большая политика, М.: РОССПЭН, 2004), однако деятельность сектора в нём проигнорирована.

19. «“Обыденное сознание любит простые решения...”: Беседа Николая Митрохина с Владимиром Александровичем Сапрыкиным», Неприкосновенный запас, М., №3 (59), 2008. [http://magazines.russ.ru/nz/2008/3/sa14.html] 
Сектор «Партийной учебы и экономического образования» (резко расширенный после 1983 года за счёт сектора партийной пропаганды), которым заведовал Николай Клепач, курировал весьма масштабную систему партийной и экономической учебы, активно создававшейся во 2-й половине 1960-х. В 1970-е-1980-е годы эта учёба фактически была обязательна для низовых партийных активистов с высшим образованием, которые стремились занять административный пост уровня директора школы или заместителя директора предприятия средней руки. Эта система предполагала 2-3 летние вечерние курсы по философским, историческим, идеологическим и (для инженеров) - экономическим и юридическим вопросам. Она существовала отдельно от системы партийных учебных заведений, которую курировали другие отделы (Орготдел и Отдел науки).

Ещё два сектора отдела - идеологического сотрудничества и контпропагандистской работы - носили полусекретный характер, насколько это было возможно в такой закрытой организации, какой был ЦК КПСС. Мне пока не удалось найти информантов, которые могли бы рассказать о работе этих секторов. Сектор идеологического сотрудничества, существовавший под этим названием после 1978 года, был наследником существовавшего с 1968 года сектора внешнеполитической пропаганды. Его передали в Отдел пропаганды из распущенного тогда Отдела международной информации. Сектор занимался преимущественно контролем за радиовещанием на зарубежные страны и, вероятно, информационной политикой ТАССа и АПН для зарубежного читателя. После воссоздания в 1978 года Отдела международной информации ЦК КПСС переименованный сектор сохранился, однако чем он занимался, не ясно. Предположительно он координировал идеологическую работу со странами Варшавского договора.

Сектор контрпропаганды, по всей видимости (прямых свидетельств тому нет, и даже информанты из других секторов не спешили делиться информацией о нём), занимался подбором информации, опровергающей «западные» утверждения об СССР, и её распространением. Во всяком случае, судя по стенограммам «брифингов» в ЦК КПСС для советских журналистов, подобные опровержения западной «клеветы» были там явлением распространенным, хотя и оглашались преимущественно заместителями заведующего отделом ${ }^{20}$.

20. Сотрудник Отдела Виктор Суханов с удовольствием описывает эпизод, как в 1977 году двое его коллег придумали вписать в доклад Юрия Андропова раздел о том, что все диссиденты финансируются западными спецслужбами и что поступать поэтому с ними надо как с обычными уголовниками. И что это было «новым словом» в идеологической борьбе, на которое сам Андропов первоначально идти не хотел. Однако этот доклад, по мнению Суханова, позволил будущему Генеральному секретарю избавиться от имиджа «либерала» у «кадровых» работников ЦК КПСС и региональных партработников. См. Суханов, Советское поколение и Геннадий Зюганов, с. 286-287. 


\section{Практики коммуникации}

В чём же заключалась повседневная служебная деятельность сотрудников отдела? Из множества коммуникативных практик, в которые она была облечена, я говорил выше о мониторинге и кадровой политике. В целом ЦК КПСС был организацией, предпочитавшей вербальные формы коммуникации и очень неохотно фиксировавшей свою «внутренюю кухню» на каких-либо письменных носителях, тем более имеющих характер официальных документов. Достаточно сказать, что из ЦК КПСС в курируемые ею организации никогда не поступало никаких официальных бумаг, за исключением общих решений Политбюро ЦК КПСС и Совета Министров СССР. В редких случаях руководителю организации для ознакомления могло быть послано - с фельдкурьером - касающееся его решение секретариата ЦК КПСС, которое должно было в течение недели (если это не документ повышенной секретности, возвращаемый сразу после прочтения) вернуться в Общий отдел ЦК КПСС. Не могло быть и речи о том, чтобы инструктор ЦК КПСС представил курируемому им чиновнику какое-либо распоряжение на официальном бланке ЦК.

То же самое касалось многочисленных форм коммуникации, которыми занимались сотрудники аппарата. Термин «телефонное право», получивший распространение во времена перестройки, не вполне описывал существовавшую практику коммуникации, но справедливо фиксировал внимание на её скрытом и вербальном характере. Помимо этого большое значение имели различные формы совещаний и консультаций, которые, как правило, не фиксировались официально, но следы их можно найти в рабочих записных книжках сотрудников аппарата и других приглашенных на эти мероприятия лиц. При отсутствии официальных стенограмм их участникам позволялось делать подобные записи, поскольку без них, в отсутствие официальных распоряжений на официальных бланках, любая деятельность если и не остановилась, то неизбежно привела бы к существенным искажениям.

Важным в этом отношении было и сложное устройство руководства самим отделом со стороны его куратора - Михаила Суслова, сочетавшее формальный и неформальный механизмы влияния. Формальный механизм был устроен строго иерархически. Отделом Суслов руководил в основном через упоминавшегося выше рабочего секретаря ЦК КПСС по идеологии, который в письменной (накладывая резолюции на документы) или устной форме передавал распоряжения заведующему отделом, а тот спускал их ниже - своим заместителям, передававшим его ниже по цепочке заведующим секторами, а те - инструкторам. Рядовые инструктора или даже заведующие секторами могли проработать в Отделе несколько десятилетий и ни разу не попасть в кабинет Суслова. Единственным способом поглядеть на него или других членов Политбюро вблизи было участие в партсобраниях аппарата, на которых эпизодически выступал кто-то из вождей.

Другой способ руководства Отделом был через помощников Суслова, которые могли позвонить лично нужному им в данный момент сотруднику 
аппарата с официальной, полуофициальной или совсем неофициальной просьбой или вопросом. Далеко не всегда это делалось по заданию самого Суслова. Помощники вполне могли предварительно разобраться в заинтересовавших их вопросах, прежде чем доложить о них шефу, а то и откровенно плести свои интриги. На последних, в частности, «погорел» один из них Владимир Воронцов. Он был членом команды Суслова ещё с 1930-х годов, занимал пост его помощника в 1953-1966 годах и был ключевой фигурой в борьбе группы сталинистов-антисемитов (и старшей сестры Маяковского - Людмилы) с влиянием Лили Брик в сфере интерпретации интеллектуального и освоения материального наследия Владимира Маяковского. В результате он был уволен из ЦК КПСС, по словам Алексея Козловского, с устной формулировкой «за действия, направленные на ухудшение отношений между советской и французской коммунистическими партиями». Сестра Лили Брик - Эльза Триоле была замужем за поэтом Луи Арагоном, влиятельным в руководстве французской компартии. И после очередной скандальной публикации в адрес Брик, инспирированной Воронцовым, Арагон напрямую обратился с протестом к Суслову ${ }^{21}$.

Помимо взаимодействия с руководством, к числу других распространенных практик работы сотрудников аппарата ЦК КПСС я отношу внешние контакты за пределами здания ЦК, экспертные совещания, координация аппарата ЦК с курируемыми им учреждениями (в частности «брифинги») и координация между отделами внутри аппарата ЦК.

Курировавший то или иное направление деятельности сотрудник отдела, как говорилось выше, отвечал за состояние дел в нескольких подведомственных ему организациях. У него было несколько способов узнавать, как обстоят в них дела.

Помимо поступающих из организации бумаг (например, ежегодных или квартальных отчётов организации перед своим министерством или перед Советом министров; экземпляров изданий, которые она публиковала; протоколов заседаний партбюро и т. п.), важными источниками были звонки от руководителей организации инструктору или наоборот. Встречи руководителей и ключевых сотрудников курируемых организаций с инструктором ЦК у него в кабинете на Старой площади также были нормой. Многие из этих людей были рады оказаться на подобной встрече, поскольку помимо решения деловых вопросов (или оглашения жалоб на коллег) она давала возможность хорошо и дешево поесть в цековском буфете (а то и, по приглашению сотрудника - в столовой, предлагавшей более широкое меню), а также купить там что-либо дефицитное и высококачественное (мясные «полуфабрикаты», фрукты, качественный алкоголь, хорошие книги) домой.

21. См. указ. выше интервью со скептически относящимся к нему А. Козловским; а также интервью Н. Митрохина с идейным соратником Воронцова, инструктором Отдела культуры Г. Гусевым. Москва, 26.01.2001, 13.6.2007. Аудиозапись и расшифровка интервью. Электронный архив автора. 
Сам инструктор отдела также периодически появлялся в курируемой организации. Однако его визиты были приурочены, как правило, к каким-то крупным мероприятиям в ней - например, проведению коллегии министерства или ведомства; перевыборам парторга; собранию с проработкой провинившихся в идеологических или иных грехах. Впрочем, были и визиты, связанные с текущим мониторингом, например, для контроля за проведением работ на крупном объекте (строительстве крупной типографии, здания нового НИИ).

Другим источником информации для аппаратчиков служили совещания с экспертами, проходившие уже на партийной территории - либо в самом здании ЦК, либо в партийных учреждениях, таких как АОН и ИМЛ, либо, в случае подготовки особо важных бумаг, - на партийных дачах. Такие совещания собирались обычно в порядке обсуждения важной, с точки зрения аппарата либо руководства партии, темы. По ней отдел пропаганды должен был подготовить «Записку», включавшую описание проблемы и предложение по мерам её разрешения. Другой причиной созыва совещаний могла быть подготовка больших докладов или выступлений первых лиц (например, на предстоящем съезде партии). Участниками совещаний обычно были люди из обкомов и республиканских комитетов партии, партийных научных и образовательных учреждений, припартийных научных учреждений (таких, как ИМРД, ИНИОН, ИМЭМО, ИЭМСС, Институт США и Канады и другие страноведческие институты), академических институтов и ведомственных НИИ, вузов (в первую очередь МГУ), редакций как партийных, так и прочих изданий, творческих союзов и псевдообщественных организаций.

В принципе круг людей, принимавших участие в таких совещаниях, мог быть достаточно широк. Он охватывал значительную часть той интеллигенции, которая напрямую коммуницировала с представителями аппарата, вполне искренне считала себя сторонниками существующей модели власти и, более того, тайно или открыто гордилась причастностью к ней. В этой связи воспроизводимая со времен эпохи перестройки во внутрироссийском дискурсе модель взаимоотношений партаппарата с интелигенцией нуждается в принципиальном пересмотре.

Фронтального противостояния партаппарата и интеллигенции, на мой взгляд, не было. Между ними существовала довольно широкая прослойка, обеспечивающая конвергенцию обеих социальных групп. Люди, которые принадлежали к творческой и научной интеллигенции и имели несомненные заслуги на этой ниве, одновременно вполне активно и нередко искренне сотрудничали с партийным аппаратом. Часть из них была бывшими или будущими сотрудниками аппарата (или их женами), но многие выполняли роль «приводных ремней», передающих волю партийных аппаратчиков интеллигенции, исходя из своих убеждений или понимая необходимость этого как часть функций должностного лица, которыми они на тот момент являлись ${ }^{22}$.

22. Другой вопрос, какое позиционирование было у этих представителей интеллигенции (особенно творческой) перед теми, кто не был вхож в партийные структуры. Перед 
Показательным в этом отношении случаем является деятельность социолога Бориса Грушина, который получал от Отдела пропаганды ЦК КПСС финансирование на свой огромный «Таганрогский проект», основной целью которого было совершенствование партийной пропаганды среди населения ${ }^{23}$. Проект этот поддерживался бывшим товарищем Грушина по комсомольскому бюро философского факульта МГУ 1950-х годов Иваном Фроловым, который стал помощником секретаря по идеологии ЦК КПСС Петра Демичева, а также получил одобрение у исполняющего обязанности заведующего отделом, Георгия Смирнова ${ }^{24}$.

Как правило, участники экспертных совещаний, организованных отделом, представляли в форме кратких докладов или записок свою позицию по обсуждаемым вопросам, а потом дискутировали между собой. Работники ЦК КПСС, участвовавшие в данном мероприятии, пытались выбрать разумные или, как минимум, приемлемые с их точки зрения предложения ${ }^{25}$. Часть этих экспертов впоследствии могла быть привлечена уже к выработке собственно документов ЦК КПСС. Нередко совещания оканчивались (с точки зрения сотрудников аппарата ЦК КПСС) безуспешно и малоэффективно, и через некоторое время они проводили следующее совещание с другим составом приглашенных.

В ЦК КПСС проводились и различные совещания с участием уже официальных представителей учреждений. Они были гораздо реже и носили в основном инструктивный характер. Наиболее регулярными и, наверное, наиболее важными среди них были «информационные совещания», чаще всего кратко и неформально именуемые «брифингами». Они собирались Отделом

членами руководства или парткома университета или редакции было вполне уместно упомянуть о визите в ЦК КПСС, а вот перед коллегами по кафедре или во время совместного распитии алкоголя в ресторане писательской организации с рядовыми собратьями по цеху по отношению к власти было вполне естественно демонстрировать скептицизм и отстранение. Влиятельные интеллектуалы, не занимавшие официальных административных постов, но «вхожие в ЦК», за пределами кабинетов руководства государственных и творческих структур старались не рекламировать конкретные случаи посещения зданий на Старой площади. При этом мотивация к посещению здания ЦК у них могла быть самая различная - от искренней поддержки власти (или отдельных группировок в ней) до тяжелой необходимости поступаться убеждениями и искать защиты или выбивать необходимые для творчества ресурсы.

23. Некоторые документы ЦК КПСС по «Таганрогскому проекту» опубликованы. См.: Л. Москвичёв, ред., Соииология и власть. 1973-1984. Сборник 3. Документы,, М.: РИЦ ИСПИ РАН, 2003., с. 102-139. Научные результаты проекта опубликованы в: Б. Грушин, Четыре жизни России в зеркале опросов общественного мнения: Очерки массового сознания россиян времен Хрущева, Брежнева, Горбачева и Ельиина в 4-х книгах, М.: Прогресс-Традиция, 2001-2004.

24. Леон Оников, «Я выполнял свой человеческий и партийный долг», в Российская социология шестидесятых годов в воспоминаниях и документах; Пресса в обществе. 1959-2000. Оценки журналистов и социологов. Документы, М.: Издательство московской школы политических исследований, 2000, с. 234; Смирнов, Уроки минувщего, c. 11-112.

25. Например, в РГАСПИ я обнаружил стенограмму совещания в Отделе пропаганды Бюро ЦК КПСС по РСФСР в 1965 году по проблемам молодежи. В нём приняли участие представители более чем 20 групп социологов из разных регионов страны. 
пропаганды примерно раз в месяц на протяжении всех 1970-1980-х годов. На них кураторы созывали главных редакторов московских изданий ${ }^{26}$. Каждый «брифинг» был посвящен одной-двум основным темам. По каждой теме обычно был краткий доклад, который делал кто-либо из высокопоставленных сотрудников аппарата ЦК КПСС, сфере ответственности которого был посвящен брифинг. В ходе «брифинга» перед редакторами раскрывалась (обычно с цифрами и фактами) проблема, волновавшая Политбюро и Секретариат ЦК КПСС, которая должна была получить развитие в прессе.

\section{Руководство отдела и политическая ориентация его сотрудников}

В 1960-е годы Отдел пропаганды был одним из фортпостов партийной ортодоксии внутри ЦК КПСС, особенно в сравнении с куда более либеральными отделами культуры и науки.

Причиной этого стал набор в него в середине 1950-х годов большой группы бывших комсомольских функционеров позднесталинского времени, свежеиспеченных выпускников АОН при ЦК КПСС.

Смена поколений сотрудников, как можно предположить, проделанная с идеей освобождения от наследия сталинизма, привлечения молодых и хорошо образованных кадров (в отличие от предшественников имевших законченное высшее образование), обернулась усиленной «сталинизацией» отдела, затянувшейся на более чем десятилетие. Профессионально сложившиеся как руководители в условиях сталинской перманентной мобилизации конца 1930-х - 1940-х годов, в атмосфере чисток, террора и кампаний по борьбе с косполитизмами - молодые функционеры попросту не знали ничего иного. Воспроизводство агрессивной риторики и морализаторства, мобилизация населения (через агитацию, принуждение и обман), поиск и разоблачение врагов да беспрекословное исполнение приказов - это было в общем-то всё, что они умели.

Значительная часть этих комсомольских функционеров, помимо сталинизма поддерживала и идеологию русского национализма. Особенно этим отличалась та часть отдела, что в 1955 году была выделена как «отдел пропаганды по РСФСР». Отдел подчинялся Бюро ЦК КПСС по РСФСР и его руководителем был военный политработник сталинского времени, убежденный русский националист Василий Московский. Фактически это была лаборатория для выращивания (или, возможно, концентрации) партийных аппаратчиков с «прорусскими» взглядами. Результаты работы этой структуры ощущались и два десятилетия спустя после её слияния с общесоюзным отделом, состоявшегося в 1965 году. Они очевидным образом сказались, например, на деятельности Бориса Стукалина (бывшего главного редактора воронежской комсомольской

26. Подробное описание «информационных совещаний» см.: Лисин, Метаморфозы дyxa, c. 526-530 
газеты), возглавлявшего отдел пропаганды в 1982-1985 годах, или заместителя заведующего отделом Егора Лигачёва, вошедшего в горбачёвское Политбюро и являвшегося главным покровителем русских националистов в перестроечном СССР.

После отставки Никиты Хрущёва Леонид Ильичёв был переведён в МИД. На его место пришел Петр Демичев, который, как выяснилось десятилетиями позже поставил своей целью «борьбу со скрытыми сталинистами» ${ }^{27}$. Действительно, к началу 1970-х годов идейный климат в Отделе пропаганды существенно изменился.

В 1965-1968 годах в рамках рутинной ротации или по причине допущенных ошибок из отдела ушли многие комсомольские функционеры призыва 1950-х годов. При этом часть из них была «твердокаменными» сталинистами, а некоторые - и русскими националистами, другие в основном были «интернационалистами» и представляли софт-линию, во многих аспектах довольно критически относящуюся к сталинскому правлению, но сохраняющую стиль поведения той эпохи. Уйдя из аппарата ЦК КПСС, все они благополучно расположились на «второй линии» партийной бюрократии - в основном в роли руководителей партийных СМИ и книгоиздания, секретарей обкомов, где проработали до 1987-1991 годов.

Самым консервативным идеологическим отделом стал отдел науки. Во второй половине 1960-х годов он был очищен от «либералов» его новым руководителем - Сергеем Трапезниковым. Отдел культуры остался (под руководством его бессменного руководителя Василия Шауро) разделенным на «ревизионистскую» и русско-националистическую фракции. Отдел же пропаганды с начала 1970-х годов был идейно (причём в рамках не просто марксистской, но официальной советской парадигмы) расколот на несколько групп, которые, впрочем, не соперничали с друг другом (как в отделе культуры), но работали в очевидном согласии.

На правом фланге располагались выжившие после чистки 2-й половины 1960-х годов сталинисты и русские националисты ${ }^{28}$. Первых, желавших реабилитации Сталина и открыто ностальгирующих по его времени, в Отделе пропаганды представляли три заведующих секторами: по союзным республикам - Николай Черных, издательств - Ираклий Чхиквишвили, внешнеполитической пропаганды - Борис Александровский ${ }^{29}$.

Русскими националистами, то есть теми, кто оказывал поддержку всему «подлинно русскому» и чинил препятствия «евреям», из числа сотрудников отдела на рубеже 1960-1970-х годов были замзав отделом Николай

27. См.: Академик Иван Тимофеевич Фролов..., с. 313-321.

28. Подробнее о русских националистах в СССР этого периода, в том числе в партийном аппарате, см.: Н. Митрохин Русская партия: движение русских националистов в СССР. 1953-1985 года. М.: Новое литературное обозрение, 2003.

29. См. интервью Н. Митрохина с В. Федининым (Москва, 03, 12, 23.04.2008 Аудиозапись и расшифровка интервью. Электронный архив автора). 
Свиридов ${ }^{30}$, завсектором журналов Иван Кириченко и его сотрудники Феликс Овчаренко и Андрей Сахаров ${ }^{31}$. Почти все они были активными участниками «Русской партии». ${ }^{32}$

Разнообразные «сусловцы» являлись идеологическим центром отдела. Сусловская парадигма восприятия действительности была довольно широка - хотя и удивляет сейчас своей схоластичностью, оторванностью от реальности. В её рамках приоритет отдавался честным, порядочным, глубоко убежденным в правоте действующей советской модели и дисциплинированным работникам с интеллигентными лицами - таким, какими стремился показать партийных чиновников советский кинематограф, описывали литераторы или изображали художники. Их символом в отделе был замзав отдела в 1969-1976 годах, профессиональный «идеологический жрец», выпускник (и на определенном этапе карьеры - глава) кафедры научного коммунизма исторического факультета Харьковского государственного университета, фронтовик-артиллерист, орденоносец, участник Парада Победы на Красной площади 24 июня 1945 года Юрий Скляров ${ }^{33}$. Таким работникам прощалась относительная независимость суждений и прямота в высказываниях.

Впрочем, было ещё немало похожих на него сотрудников отдела, которые глубоко верили в правоту партии и марксистско-ленинского учения, поскольку связывали исключительно с партией свой случай социального успеха, в духе «крестьянский сын стал доктором наук» ${ }^{34}$. И они не могли себе представить иных трактовок учения, чем те, что были изложены в последних выпусках газеты «Правда».

Другая группа сусловцев была «настоящими марксистами»- искренне убежденными в правоте марксистского учения, реально читавшими работы Маркса и активно участвующими в его защите, готовыми при том очищать бюрократию от разложившихся элементов и сажать (после дискуссии) политических оппонентов. Представителями таковых были двое опрошенных в ходе проекта - замзав отдела Ричард Косолапов и инструктор Александр Поляков, до 1970-х годов к ним относился и Наиль Биккенин.

Третья группа «сусловцев» настаивала на активной консервации существующего положения вещей. Сторонники этих взглядов видели своей основной целью борьбу с потенциальной политической оппозицией (как с диссидентами, так и с русскими националистами) не путём борьбы идей (или

30. О радикальном антисемитизме и русском национализме Н. Свиридова см., например воспоминания его протеже: И. Дроздов, Последний Иван // [http://readr.ru/ ivan-drozdov-posledniy-ivan.html?page=73]

31. Подробнее см.: Сахаров, Трудный путь в науке.

32. Подробнее см.: Н. Митрохин Русская партия, с. 126-128.

33. См. интервью Н. Митрохина с Ю. Скляровым, Москва, 04.10.2011. Аудиозапись и расшифровка интервью. Электронный архив автора.

34. См. указ выше интервью с В. Сапрыкиным: «Обыденное сознание любит простые решения...» В том же стиле указ. выше. интервью О. Сибиревой с В. Кувеневой. 
хотя бы имитации оной), но методами уголовными и административными. Проще говоря, это были типичные государственники, близкие по взглядам к сотрудникам МИДа и КГБ, которые не слишком интересовались марксизмом, но считали, что воюют с потенциальной оппозицией «в интересах страны». Выразителем этой позиции стал, возможно, самый яркий замзав отдела, куратор секторов массмедиа Владимир Севрук.

Наконец, на «левом» по меркам аппарата ЦК КПСС фланге стояла группа умеренных прогрессистов, нацеленных на постепенные изменения советской системы в сторону если не либерализации, то рационализации «идейного наследия», ухода от «догматизма», неприятия антисемитизма. Эта группа тоже была неоднородна. В ней различимы две категории: партийные схоласты в основном с философским и политэкономическим образованием, которые искали «подлинный ленинизм» (и в этом отношении были близки к сусловским «марксистам») как противовес «сталинизму», однозначными противниками которого они были, а также сторонники социализма с человеческим лицом, сочувствующие «пражской весне», связанные с прогрессистской интеллигенцией.

Первых олицетворяли и.о. завотдела Георгий Смирнов (о нём немного ниже) и заместитель заведующего отделом Вадим Медведев (будущий член горбачёвского Политбюро), заведующий группой консультантов Борис Владимиров, консультанты Лев Вознесенский и Григорий Шуйский (бывший помощник Никиты Хрущёва, который помог с публикацией «Одного дня Ивана Денисовича»). В целом они по своим взглядам совпадали с курсом рабочего секретаря по идеологии Петра Демичева, который по взглядам был «левее» (то есть на советском политическом слэнге - либеральнеее ${ }^{35}$ ) своего шефа - Михаила Суслова ${ }^{36}$. Будучи убежденными марксистамиантирыночниками, они тем не менее отличались «порядочностью» и считали, что за взгляды, в принципе, сажать не стоит.

Сторонников социализма с человеческим лицом, которым идейные оппоненты не без основания приклеили ярлык «ревизионистов» (а те, в свою очередь, его приняли и использовали во внутригрупповой коммуникации), было относительно много среди рядовых инструкторов медиа-секторов, лекторов и сотрудников группы консультантов. Наиболее крупными фигурами среди них были консультант Леон Оников и завсектора журналов после 1972 г. Наиль Биккенин. Последний, выпускник философского факультета МГУ, проделал в 1970-е годы идейную эволюцию с позиций «истинного марксиста»-ригориста к устойчивым «ревизионистам». Но даже самые

35. Советская политическая культура предполагала, что «справа» находятся сталинисты и антисемиты (с марксистскими убеждениями в их советской интерпретации), а «левые» - это сторонники социализма с человеческим лицом. Соответственно чем человек был «левее», тем он считался более либеральным в своих политических воззрениях.

36. Четко заявленную позицию Демичева о необходимости борьбы со «скрытыми сталинистами» в аппарате ЦК КПСС см.: Академик Иван Тимофеевич Фролов. Очерки, воспоминания, материалы, отв. Ред. академик В.С. Степин, М.: Наука, 2001, с. 313-321. 
радикальные «ревизионисты» не считали необходимым изменять существующую монополию КПСС на определение курса развития страны, не были сторонниками образования в СССР других партий и не обсуждали подобную возможность между собой.

Возможно, главной причиной раскола отдела на идейные группы было то, что ему «не везло» в течение 1970-х годов с руководством, которое слишком часто менялось.

Его первый (после обретения отделом в 1966 году самостоятельного административного статуса) глава - Владимир Степаков, классический партработник с невнятным техническим образованием, начавший карьеру в 1930-1940-е годы, активно поддерживал русских националистов ${ }^{37}$, был членом политической «группы Шелепина». В этой связи в 1970-м году он был удален из аппарата (как и многие другие члены группы в тот же год) на пост посла в Югославии.

Его преемник, занимавший до того пост заместителя заведующего отделом, также классический для своего времени партработник с условным высшим образованием - Александр Яковлев (будущий «архитектор перестройки»), был второстепенным членом «шелепинской» группы. Несмотря на выражение лояльности победителям во внутрипартийной баталии, личные заслуги в деле соучастия подавления «пражской весны» (где он был координатором по информационной политике и получил за «боевые заслуги» орден), а также большую популярность среди сотрудников отдела, Яковлев находился под очевидным подозрением в должности «исполняющего обязанности» в течение двух лет, до своего перемещения на должность посла в Канаду. В 1970-1972 годах он, возможно под влиянием чехословацкого опыта, успел проделать стремительную идейную революцию, превратившись из ортодоксального сталиниста с антисемитским уклоном в прогрессиста и покровителя «ревизионистов», борющегося с различными «национализмами», включая русский. За чрезмерное усердие в последнем он формально и пострадал, хотя, возможно, реальной причиной его смещения являлась былая принадлежность к группе Шелепина.

Яковлев был единственным главой отдела реализовывавшим сознательную стратегию по подбору и воспитанию кадров.

Следующим главой отдела стал прогрессистски ориентированный представитель «идеологических жрецов» из академических кругов Георгий Смирнов, за которым не водилось политических грехов. Но и он оставался в течение 6 лет «и. о.», что было абсолютным нонсенсом для аппарата, где подобный статус обычно сохранялся за человеком только в течение короткого времени. В 1978 году он передал свой пост «настоящему» завотделом, проработал в отделе до 1983 года на той же должности замзава, затем в течение

37. В. Бондаренко, «“Русский орден” в ЦК партии: мифы и реальность. Беседа с председателем Союза писателей России Валерием Ганичевым», Завтра, 2002.03.06 
двух лет возглавлял институт философии АН СССР и благополучно вписался в «команду Горбачёва», став его советником.

Лишь в 1978 году отдел получил руководителя без приставки и. о. - им стал Евгений Тяжельников, пришедший на эту должность с поста первого секретаря ЦК ВЛКСМ. Политически он однозначно ориентировался только на Леонида Брежнева и опирался де-факто только на его поддержку. Критики, в том числе внутри отдела, обвиняли его в многочисленных грехах, начиная от непрофессионализма, «показушничества», заканчивая фаворитизмом и гомосексуализмом $^{38}$. С точки зрения политических взглядов он был умеренным сторонником русского национализма. В 1982 г. он разделил участь большинства предшественников на этом посту, отправившись возглавлять советское посольство в Румынию.

На место Тяжельникова стал просталински-ориентированный умеренный русский националист, с большим опытом работы в партийных органах и сфере книгоиздательства - Борис Стукалин. Он был членом малочисленной и гиперконсервативной даже по меркам ЦК КПСС группировки, идеологически мутировавшей в сторону неосталинизма и пользовавшейся огромным влиянием в эпоху Константина Черненко ${ }^{39}$. Судьба Стукалина с приходом Горбачёва сложилась также, как и у предшественников - он был отправлен послом в Венгрию, а затем на пенсию.

Вышеописанное идейное разнообразие в отделе - не только дань частым переменам в составе руководства. Важными факторами тут являлись и величина отдела, усложнявшая задачу по его идейной унификации; и тот факт, что значительная часть сотрудников, формально приглашенная на работу руководством отдела, реально была довольно тесно связана с политическими фигурами первого ряда - секретарями и членами политбюро ЦК КПСС.

Так что даже если кто-то из руководства (как, например, Тяжельников) ставил бы своей задачей увольнение кого-то из сотрудников без весомых причин, а только из-за несовпадения взглядов с руководством, это могло иметь для него значительные и неприятные последствия ${ }^{40}$.

С другой стороны, несмотря на наличие собственных политических взглядов, сотрудники отдела были повязаны дисциплинарной ответственностью. Приказы и распоряжения непосредственного начальства не подлежали обсуждению и сотрудник должен был их исполнить. Однако, если они сильно

38. См.: Смирнов, Уроки минувщего, с. 140-141» (о «показушничестве»); Суханов, Советское поколение и Геннадий Зюганов, с. 81 (о гомосексуализме); указ. ранее интервью с А. Козловским.

39. См.: Суханов, Советское поколение и Геннадий Зюганов, с. 293; интервью Н. Митрохина с Р. Косолаповым, Москва, 19, 27.06.2007; 24.01, 21.02, 10.09. 2008. Аудиозапись и расшифровка интервью. Электронный архив автора.

40. Например, Е. Тяжельников находился в глубоком личном конфликте со всеми основными сотрудниками сектора журналов, которые в то же время постоянно писали доклады членам Политбюро, и потому держали себя уверенно. См.: интервью Н. Митрохина с А. Козловским; Лисин, Метаморфозы духа, с. 442, 523-524. 
расходились с его принципами и убеждениями, особенно если носили репрессивный характер, то он мог дать понять намеченным жертвам, как им лучше поступить, чтобы минимизировать ущерб. Например, обойтись без, казалось бы, неизбежного увольнения, заменив его в идеале на безобидный с административной точки зрения «выговор без занесения». Или провести «воспитательную» работу формально, или не провести её вовсе, понадеявшись на забывчивость начальства.

В случае если проблема требовала более системных действий, сотрудник мог задействовать сеть единомышленников из числа работников отдела, аппарата ЦК КПСС в целом, покровителей из числа членов Политбюро, Секретариата ЦК, помощников первых лиц. Также могли использоваться силы и влияние сотрудников других учреждений и ведомств, общественных деятелей и т. п. Впрочем, мог сотрудник отдела действовать и под их влиянием, и в их интересах.

В этом отношении работники Отдела пропаганды были серьезно вовлечены в различные социальные сети, построенные внутри части элитарных групп советского общества ${ }^{41}$. Их организовывали выходцы из комсомольского аппарата, академическая и университетская гуманитарная интеллигенция (и особенно «идеологические жрецы»), а также журналисты и издатели из столичных, республиканских и областных центров $\mathrm{CCCP}^{42}$; сообщества выпускников элитарных вызов, таких как МГУ, ЛГУ и МГИМО.

Разумеется, в большинстве случае вовлеченность в деятельность этих сетей не означала их использования в режиме конфронтации с руководством или коллегами. Наоборот, эти сети создавались для взаимоподдержки и получения всеми их участниками максимума общественных благ.

Но, повторюсь, работала эта сеть, когда не было иных, прямых указаний сверху с предполагаемой жесткой ответственностью за неисполнение.

В целом, обозревая перемены внутри руководства отдела, можно констатировать, что Суслов, по видимому, полностью сдал дела Отдела пропаганды (в том числе вопросы формирования его кадрового состава) в руки рабочего секретаря ЦК КПСС - кто бы тем ни был. И не интересовался ими в объёме большем, чем требовалось для исполнения его непосредственных поручений и общего поддержания порядка («партийной дисциплины») в нём.

«Антисталинист» Петр Демичев на посту «рабочего секретаря» поэтапно вычистил из отдела практически всех «скрытых сталинистов» и русских националистов. В 1973-1974 годах их реальное влияние в отделе упало почти до нуля. Уход Демичева в конце 1974 года и назначение на эту должность в марте 1976-го Михаила Зимянина, с конца 1960-х стремительно мутировавшего в своих политических взглядах от относительного партийного либерализма

41. Подробнее см.: Н. Митрохин, «Личные связи в аппарате ЦК КПСС», Неприкосновенный запас, №3, 2012, с. 166-175. [http://magazines.russ.ru/nz/2012/3/m13.html]

42. Начав подсчитывать только известные мне случаи приёма на работу в Отдел пропаганды представителей провинции, я набрал до полутора десятков примеров, охвативших территорию России (от Архангельска до Краснодара), Украины (от Харькова до Львова), Белоруссии, Казахстана и Грузии. 
к довольно деятельному русскому национализму ${ }^{43}$, ознаменовались отстранением из руководства отдела условных прогрессистов и поочередным приходом на должности руководителей отдела умеренных русских националистов, а также усилением влияния «государственника» Владимира Севрука.

\section{Формирование и обновление системы советских культурных символов у сотрудников Отдела пропаганды}

Говоря о коммуникативных практиках работы в ЦК КПСС, мы видим, что принципы заказа и отбора «советских» культурных символов не базировались на каких бы то ни было письменных инструкциях или жесткой и где-либо закрепленной системе (кодексе) идеологических норм. Де-факто они существовали в головах их носителей. На каждом уровне иерархической вертикали чиновник разрабатывал границы того, что можно, а что нельзя, сверяясь с мнением начальства, обращая внимания на мнения коллег и экспертного круга, но и руководствуясь собственными представлениями о том, что допускает (и представляет собой) исповедуемая им идеология, которую он ассоциировал с марксизмом-ленинизмом. Ответы бывших сотрудников аппарата на мои вопросы о прочитанной ими марксистской литературе, о значимых для них текстах, на которых опиралась их позиция и ответы на них, демонстрируют, что за редким исключением их «марксистское» образование осталось на уровне чего-то сданного и забытого в вузе.

Тем не менее они имели представление о том, что хорошо, что плохо, что соответствует идеологии, что нет, что является советским, а что - нет. Откуда же это представление взялось?

Может быть, это результат опосредованного воздействия - через научные и политические журналы, систему образов, предложенных средствами передачи актуальной политической культуры - телевидением, кино, театром?

Опрос бывших работников ЦК КПСС об их культурных предпочтениях и источниках информации о событиях в мире демонстрируют удивительную бедность таковых. Да, они все читали газету «Правда», чтобы быть в курсе актуальной политической повестки дня. Но подобные газеты не формируют мировоззрение. Научные журналы, включая партийный теоретический журнал «Коммунист», из них читали единицы. Художественная литература, выходящая за пределы насущной профессиональной необходимости, за исключением отдельных «прозвучавших» произведений (и то в эпоху перестройки), у них популярностью не пользовалась. На книги, по словам респондентов, просто не хватало времени и сил, после целого дня чтения деловых бумаг и другой интенсивной интеллектуальной деятельности.

43. Подробнее об этом см.: Митрохин, Русская партия, с. $85,122,123,537-538$. О Зимянине существует и апологетическая книга, написанная его сыном Владимиром (под псевдонимом), в которой довольно много написано о его «державных» взглядах: Михаил Бублеев, Непобеждённый, Изд. «Городец», 2004, 2008 гг. 
Телевидение они смотрели гораздо меньше, чем обычные советские зрители - поскольку обычно возвращались с работы домой к вечерней программе «Время» и должны были довольно рано ложиться спать, чтобы не позже 9 утра быть на работе. Всё, что им запомнилось из советского телевидения этого периода, - спортивные программы и детективные телесериалы. На выходных большинство из них уезжало в санатории ЦК, где они предпочитали тратить время на прогулки в парке, занятия спортом, игру в бильярд.

В качестве единственного источника систематического культурного воздействия значительное количество опрошенных работников аппарата указали театры. Благо добыть билет на любой спектакль им не составляло никакого труда через театральную кассу ЦК КПСС. Однако ходили они в основном на классические спектакли или на постановки западных авторов. Актуальные советские пьесы их особенно не интересовали (кроме постановок престижного Театра на Таганке, да и то у меньшинства из «театралов»).

Между тем, несмотря на разницу в политических позициях, у работников аппарата ЦК КПСС наблюдалась определенная культурная гомогенность, заявленная, в частности, в их интервью и мемуарах. Они были действительно советскими людьми. Как же всё-таки это сформировалось?

Ответ на этот вопрос можно найти, если рассмотреть социальный и возрастной состав сотрудников аппарата. Работники аппарата ЦК КПСС 1965-1985 годов были гомогенной группой не только с точки зрения культурных, но и социальных показателей. Комплекс из 191 подробных биографий работников ЦК КПСС этого периода (из них работники идеологических отделов - 54), составленных на основе интервью, мемуаров и сведений, предоставленных мне родственниками, даёт удивительно однородную картину.

Это в основном мужчины, пришедшие в аппарат ЦК КПСС в возрасте около 35-40 лет. На более чем 85\% это русские, восточные украинцы, белорусы, которые в трех поколениях вообще не имеют никаких иноэтничных предков (или не знают о них). 70\% из них выросли в семьях от среднего и высшего класса сталинского времени. Их родители работали в диапазоне от бухгалтера предприятия, армейского офицера, председателя колхоза до директора завода и заместителя министра. По своему социальному происхождению родители в равной степени (и нередко в рамках одного брака) представляли дореволюционный средний (иногда - высший) класс и новых «служащих», сделавших советскую карьеру благодаря участию в революции, Гражданской войне или прокоммунистическому активизму (комбеды, исполкомы, комсомол, служба в армии и ОГПУ-НКВД) в 1920-е годы. Как минимум 76,1\% будущих работников ЦК КПСС имели полную семью до момента окончания школы.

Спецификой собственно отдела пропаганды является то, что весомая часть его сотрудников вышла из семей с высоким уровнем интереса либо к политике, либо к религии. Так, например, пять сотрудников отдела пропаганды, из 36 , чьи биографии вошли в рассматриваемый биографический массив (и лишь в двух случаях - сотрудники других отделов), заявили о 
своём родстве с видными политическими деятелями дореволюционного времени. В их числе оказались трое депутатов Государственной думы от разных левых партий ${ }^{44}$. Кроме того, упоминавшийся выше Алексей Козловский был внучатым племянником двух членов Государственного совета Российской империи, а Юрий Сапожников - внуком видного народовольца, ставшего затем заметным эсером на Юге России ${ }^{45}$.

Что касается интереса к религиозности, то в этом отношении сотрудники отдела пропаганды были не уникальны, в других отделах также были люди с детским религиозным опытом или воспитанные в религиозных семьях, однако в процентном отношении сотрудники отдела пропаганды составляют около $80 \%$ от числа людей, заявивших об этом.

Другой вопрос, что будущие работники отдела примерно к 12 годам разрывали все связи с прошлым - как религиозным, так и «несоветским»-семейным. Сохраняя высокий уровень интереса к абстрактным идеям, они переключались на новую веру, которая «сияющей дорогой строительства коммунизма» твердо вела их к социальному успеху.

На мой взгляд, можно выделить три наиболее существенных фактора в формировании менталитета работников аппарата ЦК КПСС.

Первым из них было то, что $80 \%$ из них получили полное среднее образование в советской школе. Остальные (за двумя исключениями) окончили техникумы (почти все с красным дипломом). Из числа окончивших среднюю школу не менее $34,7 \%$ (в том числе среди сотрудников идеологических отделов - не менее 55\%) получили на выходе атестат об отличии, золотую или серебряную медаль. Школы, которые они окончили (преимущественно в 1930-х - начале 1950-х годов) были в основном «хорошими школами», располагавшимися в центре городов. Другим важным обстоятельством являлось активное участие будущих работников ЦК КПСС в общественной деятельности на школьном уровне, в частности тот факт, что высокий процент их них (по далеко не полным данным - 37,9\% в целом по массиву и 49\% для сотрудников идеологических отделов) становился председателями пионерской дружины или комсоргами школ.

Вторым фактором было массовое поступление этих детей в вузы, в том числе их учеба в наиболее крупных и престижных вузах страны - МГУ, МГИМО, ЛГУ. 55,5\% из нашего биографического массива учились в московских вузах, дававших наиболее качественное в стране образование (из числа сотрудников идеологических отделов - 50\%). Почти половина из них (и

44. Н. Биккенин (брат деда по матери - депутат фракции кадетов от Оренбургской губернии Зигангир Нургалиевич Байбурин (1852-1915), врач, лидер панисламистской политической организации), В. Костров (прадед по отцу - Андрей Михайлович Костров (1856-не ранее 1916), волостной старшина и член ростовской земской управы, оптовый торговец, депутат фракции кадетов первой государственной думы), В. Михайлов (муж правнучки депутата от фракции трудовиков первой государственной думы, учителя, мирового судьи Кирилла Семёновича Нечипоренко (1855-не ранее 1916)).

45. Предоставленные сведения были проверены и получили подтверждение. 
четверть от массива) учились в МГУ и МГИМО. Среди сотрудников идеологических отделов таких было $38,2 \%$ от общего количества или три четверти учившихся в Москве (21 из 27). В ЛГУ и других ленинградских вузах учились ещё шестеро (4 и 2 соответственно). И хотя успехи их в учебе были не такие яркие, как в школе, но тем не менее образование они получили полное и, что не менее важно, продолжали активно участвовать в политической деятельности - были комсоргами и членами партбюро. Учеба подавляющего большинства из них пришлась на период 2-й половины 1940-х - 1950-е года.

Третьим фактором стало получение частью их них, прежде всего теми, кто не учился в аспирантуре после окончания в вузе, дополнительного идеологического образования в стенах Академии общественных наук при ЦК КПСС (AОН). Двухлетняя учеба в АОН была последним периодом, когда они имели возможность читать серьезную литературу и закреплять в голове идеологические концепции, передаваемые им преподавателями.

Таким образом, работники аппарата ЦК КПСС в целом и отдела пропаганды - в частности, были в первую очередь лучшими воспитанниками «хорошей» сталинской школы и идеологических факультетов лучших вузов страны. Это обеспечивало им единый и довольно сильно унифицированный культурный базис. Который заключался не только и не столько в апологетике самого Сталина (отношение к которому было разным и нуждается в отдельном описании ${ }^{46}$ ), сколько в аппеляции к неизменным и не подвергавшимся сомнению культурным нормам.

Что писали русские классики и как надо правильно их цитировать. Какие советские писатели важны. Какие марксистские авторы важны и какие их работы нужно изучать. Кого из иностранных авторов должен знать культурный человек (который при случае может и иностранца «посрамить» правильно ввернутой цитатой из Шиллера или Гёте). Что однозначно доказано исторической наукой (особенно в сфере истории дореволюционной России) и каких исторических персонажей должен знать образованный человек. Что такое заграница и как там думают, как относятся к русским и Советскому Союзу. Кто были герои революции. Какие были предатели родины после революции (с небольшими поправками на реабилитированных, про которых написали в прессе и мемуарах советских полководцев). Каких героев Великой Отечественной войны надо помнить.

Всё это сохранялось в качестве непреложной истины, незнание которой или тем более сомнения в которой вызывают у информантов и мемуаристов откровенные порицания в адрес молодых поколений. Дискуссия с работниками аппарата ЦК КПСС по этим символами была невозможна, поскольку для них, отличников в учебе, один раз выучивших, что правильно, а что - нет, любая другая интерпретация означала попросту неверный ответ,

46. Оно сделано мною в следующей статье: Н. Митрохин, «Личная память о «репрессиях» у работников аппарата ЦК КПСС 1960-х-1980-х гг. и её политические последствия», в А. Сорокин, А. Кобак, О. Кувалдина, сост., История сталинизма: Жизнь в терроре. Социальные аспекты репрессий, М.: РОССПЭН, 2013, с. 60-83. 
рассматривавшийся в парадигме советское-«антисоветское». Чтобы избежать встречи с «антисоветским», которое травмировало их своей неправильностью, работники Отдела пропаганды, даже не являющиеся представителями консервативного крыла или недалекими региональными партработниками, отказывались читать «тамиздат», хотя он был им при желании доступен. То есть слушать по радио западные новости на русском языке они были готовы, но читать что-либо более содержательное, развернутое они решительно не хотели. Поскольку им было это (как многократно прозвучало в интервью) «не интересно».

Учеба в вузе, аспирантуре или в АОН приводила их, правда, к некоторым подвижкам в своей позиции, поскольку образование в сталинской школе все равно не могло дать ответа на все вопросы мироустройства и политической реальности. Однако они готовы были находиться только в рамках заложенной идейной парадигмы, в диапазоне между ревизионизмом и сталинизмом, извлекая из своего школьного опыта и рассказов родителей те факты и свидетельства, которые подтверждали благоприобретенную политическую позицию.

Они жили в этом отношении в гомогенном идеологическом мире. Например, согласно подавляющему большинству интервью, никто из опрошенных ни разу в жизни не слышал своими ушами от живого человека (а не от зарубежного радио) каких бы то ни было «антисоветских заявлений» или сколь-нибудь систематической критики власти. Это совершенно не удивительно, поскольку, будучи с детства убежденными сторонниками власти, они исключали возможность сближения с ними критически настроенных сверстников, а вырастая, окончив вузы, они исключали все «сомнительные» контакты, дружбы и связи из своего окружения. Новые знакомства возникали только в кругу коллег, профессиональной среде, в которую они были включены по работе, или среди близких по социальному статусу людей, - с которыми, например, они отдыхали в партийных санаториях.

Они были советскими людьми, общались с советскими людьми и думали, что всё иное, чуждое, несоветское на территории СССР есть ошибка, которую просто нужно исправить - убеждением или насилием. В плакатах и фильмах, газетах и телевизионных передачах они искренне обращались к советскому человеку, которого видели таким, каким были они сами - средних лет, трезвому, аккуратно одетому, бритому, с честным лицом и партийным билетом у сердца (или комсомольским значком на рабочей спецовке), интересующемуся итогами очередного пленума и намеренному обсудить их на комсомольском или партийном собрании.

По их мемуарам или первым ответам на вопросы в интервью можно предположить: они всерьез полагали, что такие люди действительно существуют за пределами зданий партийных и комсомольских комитетов, в которых проходила вся их жизнь на протяжении десятилетий, и за пределами того круга руководителей и экспертов, с которыми они привыкли общаться как с представителями «народа». 
Но если пойти подальше и начать «царапать» их внешне незамутненное ощущение полной «советскости» советского общества вопросами о соответствии мифов - реалиям, довольно быстро в их раздраженных и отрывистых ответах, грозящих преждевременным окончанием интервью, выясняется нечто иное ${ }^{47}$. У значительной части из них - и тех, кто с опытом региональной партийной работы и тех, кто пришёл из московской интеллигенции, имелось твердое чувство, что где-то внизу что-то всерьёз было «не так». Никак не соответствовало тому, что они сами официально утверждали. Но это была не их, высокопоставленных партийных чиновников, забота. Разбираться с проблемами должны были те, кому это положено - сотрудники низовых структур (и партийных, и государственных), КГБ или милиция. Но не они, которые должны были задавать стандарты: как должно быть правильно - и контролировать их исполнение.

Был ли таковым и Алексей Козловский, который по своему интеллектуальному уровню и заслугам в сфере книгоиздания выделялся на фоне других сотрудников отдела?

Да, во многом был. Перенятая у отца суровая маска «служения государству» оказалась очень выигрышной для построения карьеры и отстранения от интеллектуального, артистического и потому потенциально опасного мира матери. Он отказался участвовать в контактах с заграничными родственниками, которые поддерживали сначала его бабушка, потом мать. Это было несомненно опасно для карьеры. Тем более что, как я выяснил независимо от него, его двоюродные братья от его дяди, бывшего репрессированного инженера, сдавшегося в плен вермахту во время Второй мировой войны и переселившегося по её окончании в Аргентину, были активными антикоммунистами. Один из них публиковался в монархической газете «Наша страна» (активно используя цитаты из русских поэтов Серебряного века), другой был старостой прихода РПЦЗ в Мюнхене.

Очевидный логический разрыв между «несоветским» семейным и отчасти университетским интеллектуальным прошлым и успешной карьерой Козловский компенсировал (во всяком случае в интервью) когда иронией, а чаще скепсисом и гиперболизированными уничижительными характеристиками в отношении практически всех упоминаемых им персонажей и текстов. Исключение из тотальной критики делалось им лишь для своих старших родственников и части их знакомых; узкого круга литераторов Серебряного века, публикацией которых он занимался; некоторых бывших коллег по идеологической работе и специалистов-литературоведов, с которыми он был лично знаком.

Был ли Козловский таким единственным в отделе? Разумеется, нет. Его единомышленник и начальник Владимир Севрук был сыном заметного белорусского литератора, пережившего репрессии. Сам Севрук в 1955 году, сразу после окончания факультета журналистики Белорусского университета, 
приехал в Магадан, где был не только секретарем областного комитета комсомола, но и основателем газеты «Магаданский комсомолец». То есть, как и Козловский, знал и о репрессиях, и о том, как выглядит хорошая литература, вполне достаточно.

Предшественник Козловского на посту заведующего сектором журналов, Наиль Биккенин, был не только внучатым племянником депутата Государственной думы, но и сыном рафинированных казанских интеллектуалов, выходцев из семей муллы и крупного зерноторговца. Его отец уже после войны подвергался преследованиям - за попытку в начале 1930-х годов отстоять сохранение арабского алфавита для татарского языка. Биккенин настойчиво утверждал в своих воспоминаниях, что «не хотел бы спекулировать» на теме репрессий против родственников - некоторые из которых были уничтожены советской властью ещё в ходе Гражданской войны, а другие отсидели в период репрессий. И предельно уничижительно отзывался о тех, кто, по его мнению, такими «спекуляциями» занимался ${ }^{48}$.

Подобные примеры можно множить, хотя далеко не все биографии сотрудников отдела известны в подробностях. Не ошибусь, если скажу, что от трети до половины опрошенных и мемуаристов из числа сотрудников Отдела имели и высокий интеллектуальный уровень, и тот или иной значительный объём «несоветских» знаний, которые они совершенно не стремились демонстрировать коллегам и уж тем более «начальству». Однако невзирая на свои профессиональные достижения на неидеологическом поприще, начав свою партийную карьеру, эти люди сознательно приводили себя к «среднему знаменателю», сконцентрировав свои интеллектуальные интересы на безопасных темах. И использовали свои более широкие знания и былые увлечения для борьбы с тем, что их менее начитанные коллеги однозначно считали антисоветским.

\section{Заключение}

Явление «застоя» невозможно понимать без осознания того, чем являлся предшествующий ему период советской истории. Бесконечные, противоречивые и довольно серьезные реформы аппарата управления и идеологической сферы, начатые сразу после смерти Иосифа Сталина и продолжавшиеся в течение двенадцати лет (1953-1965), породили внутри политической элиты страны, чиновничества (как социальной группы) и большого количества рядовых граждан запрос на стабильность. В этом, на мой взгляд, состоял внутриполитический успех концепции стабильности, негласно выдвинутой Брежневым и его окружением. Именно этот концепт помог «брежневцам» победить конкурирующую политическую группу, сформировавшуюся вокруг 
Александра Шелепина, которая намеревалась продолжать реформы (пусть и в своей трактовке) и чистки бюрократии.

Запрос на стабильность в сфере идеологии на практике балансировал между желанием одних групп чиновников укрепить её путём отката назад к признанию «величия Сталина» и возобновлению практики политических репрессий - и намерением других групп чиновников закрепить достигнутые свободы и без особых рывков в дальнейшем искать всё же путь к «подлинному ленинизму». Под ним понималось осторожное движение от диктатуры к модели всё более плюралистического общества, утопическому «новому НЭПу» без нэпманов, троцкистов и сталинистов. Однако большинство аппаратчиков, на мой взгляд (и по моим опросам), хотело просто стабильности - спокойной работы, вежливого обращения со стороны начальства, гарантированного, говоря современным языком, «социального пакета», отсутствия тревожащих новостей в СМИ, предсказуемой внешней политики.

Помимо того, стабильность работы огромного идеологического механизма по заказу, производству и распространению советских культурных символов; механизма, который формировал всё новые поколения советских людей, имела несколько серьезных причин.

Первая из них заключалась в том, что этот механизм работал в пользу небольшой группы людей - членов Политбюро, которые чётко представляли, что они хотят (а хотели они прежде всего сохранения своей власти), и умели этим механизмом пользоваться.

Второй причиной являлось разделение ответственности за формирование и продвижение советской идеологической доктрины и связанных с ней культурных символов между партийным аппаратом и множеством других учреждений и организаций, а также экспертным сообществом, представителями медиа и другими элитарными и высокообразованными профессиональными группами.

Третьей причиной являлась многофункциональность центрального ядра данной системы - группы идеологических отделов аппарата ЦК КПСС. В частности, важными функциями этих отделов была компенсаторная и посредническая. С одной стороны, они служили посредником между «творцами» (представителями «творческих союзов», издателями, журналистами, учеными, преподавателями) и «сторожевыми псами» (КГБ, Главлитом), переводя пожелания первых в форму, понятную принимающему окончательное решение высшему партийному руководству, и смягчая рвение вторых. С другой стороны, они были посредниками между различными группировками внутри элитарных групп интеллигенции.

При этом разброс мнений сотрудников ЦК КПСС о том, что соответствует советской идеологической модели, а что нет, усиливали, а не ослабляли систему. Каждый из «творцов» (включая «идеологических жрецов»), если он действительно был «советским человеком» (то есть стремился вписать своё творчество в рамки устанавливаемые отделом пропаганды), мог найти в аппарате ЦК КПСС своего защитника, человека, к которому он мог обратиться 
за посредничеством в конфликтах с идейными (или профессиональными) конкурентами или карательными органами.

Четвертой причиной было то, что советский идеологический механизм в 1960-первой половине 1980-х годов работал в культурно комфортной ему среде. Не только в ЦК КПСС, но и во всех идеологических, научных, культурных и образовательных учреждениях, во всяком случае на командных позициях, работали «советские люди». Люди, выросшие в СССР, проникнутые советской идеологией, люди схожего социального происхождения, окончившие те же вузы, что и работники аппарата ЦК КПСС, учившиеся примерно в то же, послевоенное, время, говорящие с ними на одном языке и разделяющие одну систему если не ценностей, то культурных образов.

Управлять такой средой можно было уже без террора и чисток, оперируя лишь угрозой увольнения, зачисления в список «невыездных» или запрета на публикацию. Другой вопрос, что подобная культурная гомогенность оказалась возможна только у поколений, выросших в условиях террора и чисток. Будучи детьми и подростками, они получали общественно-важную, мировоззренческую информацию только из школьных учебников и радиопередач. Никто, даже родители, не предлагали им иной точки зрения и у массовой пропаганды не было никакой позитивной (т.е. не криминальной) альтернативы. У всех последующих поколений было существенно больше информации и потому слишком много вопросов, на которые советская культурная модель не могла дать убедительных ответов.

Что, конечно, не было единственной причиной её краха, но имело существенное значение в период «перестройки». Её делали в качестве членов Политбюро сразу три бывших руководителя отдела пропаганды 1960-х-1970-х годов - Лигачёв, Медведев и Яковлев ${ }^{49}$. По прошествии двух десятков лет «застоя» они естественным образом переросли «стабильность», осознали необходимость новых реформ и обновления кадрового состава бюрократии всех уровней. Другой вопрос, что у каждого из них (и других руководителей страны) представление о масштабах необходимых реформ и возможной их направленности существенно различалось и более того менялось по мере их реализации. В этом отношении сработали те различия в трактовке официального советского марксизма, анализу которой в данном тексте посвящено столько места.

49. А среди руководителей ведомств СССР периода перестройки - ещё пятеро бывших сотрудников отдела - М. Грамов (Госкомспорт), В. Захаров (Министерство культуры), Л. Кравченко (Гостелерадио), М. Ненашев (Госкомиздат, Гостелерадио, министр печати и информации), Н. Русак (Госкомспорт). Двое сотрудников отдела (С. Арутюнян и П. Лучинский) стали в перестройку первыми секретарями республиканских комитетов партии (Армении и Молдавии). 
Но одним из самых серьезных их заблуждений являлась твердая уверенность в том, что «пряник» советской пропаганды может (ре)формировать общество сам по себе, без «кнута» КГБ 50 . О том, что это не так, они узнали, к счастью, слишком поздно ${ }^{51}$. И узнав, к их чести, не стали поворачивать обратно.

Центр по изучению Восточной Европы при Бременском университете, Германия

mitrokhin@uni-bremen.de

50. См. подробное описание подготовки доклада М. Горбачёва на XXVII-м съезде КПСС А. Яковлевым и сотрудниками отдела: Лисин, Метаморфозы духа, с. 556-563.

51. Подробнее моя позиция по этому вопросу изложена тут: Nikolay Mitrokhin, “'Strange People' in the Politburo Institutional Problems and the Human Factor in the Economic Collapse of the Soviet Empire," Kritika: Explorations in Russian and Eurasian History, 10 (4), Fall 2009, c. 869-896. 